\title{
Факторный анализ недревесной продукции леса Бугульминско-Белебеевской возвышенности Башкирии
}

Хисамов Р.Р., Мазуркин П.М., Рахматуллина И.Р.

Введение. Бугульминско-Белебеевская возвышенность в пределах Республики Башкортостан занимает западную приподнятую окраину республики и является одним из наиболее промышленно развитых, густонаселенных и лесодефицитных районов (рис. 1). По лесорастительному районированию территория отнесена к лесостепной зоне и лесостепному району Европейской части Российской Федерации.

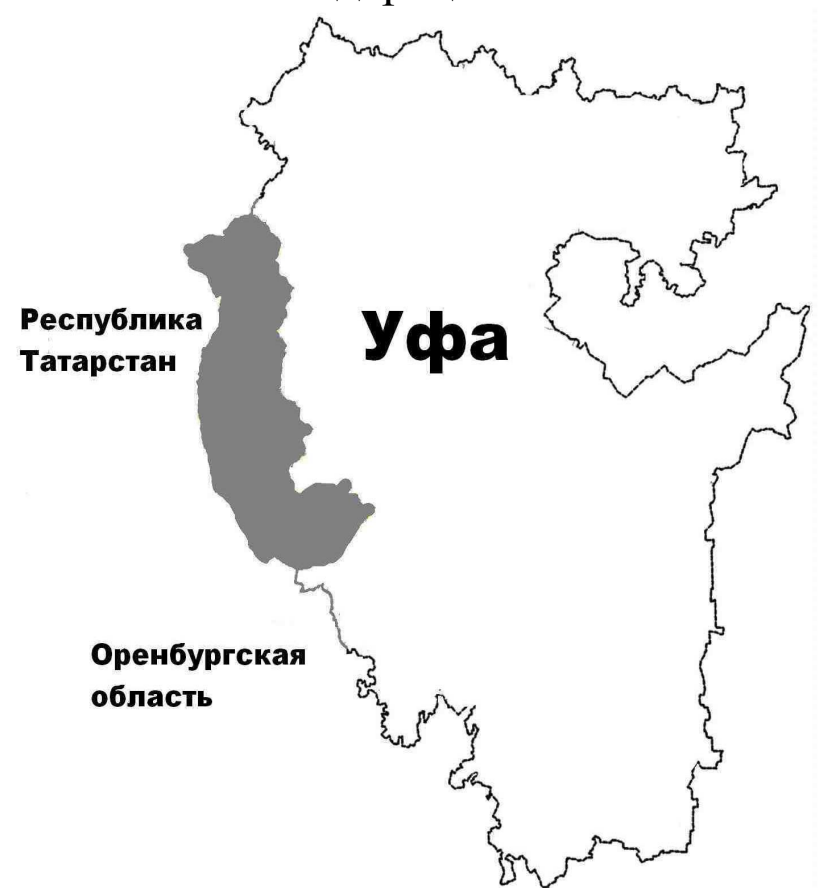

Рисунок 1. Бугульминско-Белебеевская возвышенность в пределах территории Республики Башкортостан

Исходные данные выбирались из годовых отчетов лесничеств за 8 лет (2006-2013 гг.) [6, 7].

Факторный анализ в общем случае проводится в четыре этапа:

1) выявление закономерностей рангового распределения по факторам;

2) выявление биотехнических закономерностей бинарных отношений между учитываемыми факторами;

3) рейтинг учтенных факторов по строкам (факторы как влияющие переменные) и столбцам (факторы как зависимые показатели) по общей корреляционной матрице;

4) рейтинг бинарных отношений по коэффициенту корреляции.

Второй этап подробно показан в публикациях [1-5].

В статье покажем методику по четвертому этапу факторного анализа.

Из-за периода времени за 8 лет динамики показателей были определены средние значения из данных таблицы 1 и таблицы 2 (всего 17 факторов) по 7 районам. Факторный анализ [1-5] нами проведен с применением детерминированной общей закономерности в виде суммы двух биотехнических законов

$$
y_{m}=y_{m 1}+y_{m 2}, y_{m 1}=a_{1} x^{a_{2}} \exp \left(-a_{3} x^{a_{4}}\right), y_{m 2}=a_{5} x^{a_{6}} \exp \left(-a_{7} x^{a_{8}}\right),
$$

где $y_{m}$ - тренд показателя, $x$ - объясняющая переменная, $a_{1} \ldots a_{8}$ - параметры модели (1), получаемые в CurveExpert (URL: http://www.curveexpert.net/).

Для выявления волновых членов дополнительно к тренду (1) необходимо множество из не менее 20 районов, то есть в дальнейшем придется рассматривать все муниципалитеты Башкирии, включая и города. В этом случае в городах будут показатели, по своим значениям приближающиеся к нулю. А после этого предлагаемую методологию факторного анализа можно рекомендовать для всех субъектов федерального округа и даже всей Российской Федерации. 
Исходные данные. Табличные данные для статистического моделирования [6] даны в таблице 1 и таблице 2.

Таблица 1

Распределение земель по районам на Бугульминско-Белебеевской возвышенности по категориям земель, тыс.га

\begin{tabular}{|c|c|c|c|c|c|c|c|c|c|}
\hline \multirow[b]{2}{*}{ Район } & \multirow[b]{2}{*}{\begin{tabular}{|c} 
Общая \\
площадь \\
$S$
\end{tabular}} & \multirow{2}{*}{$\begin{array}{c}\text { Земли сельско- } \\
\text { хозяйственного } \\
\text { назначения } \\
S_{c x y}\end{array}$} & \multicolumn{6}{|c|}{ Земли лесного фонда } & \multirow[b]{2}{*}{$\begin{array}{c}\text { Прочие } \\
\text { земли } \\
S_{n p}\end{array}$} \\
\hline & & & $\begin{array}{c}\text { песопок- } \\
\text { рытые } \\
S_{л n}\end{array}$ & \begin{tabular}{|c|} 
pe- \\
дины \\
$S_{p}$, га
\end{tabular} & $\begin{array}{c}\text { вы- } \\
\text { рубки } \\
S_{в}, \text { га }\end{array}$ & $\begin{array}{l}\text { прога- } \\
\text { лины } \\
S_{n p}, \text { га }\end{array}$ & $\begin{array}{c}\text { сено- } \\
\text { косы } \\
S_{c}\end{array}$ & $\begin{array}{c}\text { паст- } \\
\text { бища } \\
S_{n}\end{array}$ & \\
\hline Бака. & & 119.70 & 59.930 & 39 & 1063 & 176 & 1.543 & 1.011 & 11.490 \\
\hline Белебеевский & 185.58 & 107.82 & 63.093 & 65 & 889 & 279 & 1.328 & 1.046 & 8.937 \\
\hline Бижбулякский & 213.39 & 160.08 & 32.520 & 91 & 276 & 381 & 0.707 & 0.524 & 18.815 \\
\hline Ермекеевский & 143.43 & 109.58 & 15.098 & 15 & 94 & 104 & 0.415 & 0.510 & 12.114 \\
\hline Миякинский & 205.13 & 150.82 & 30.329 & 104 & 265 & 214 & 1.195 & 0.636 & 14.396 \\
\hline Туймазинский & 235.78 & 136.77 & 68.389 & 97 & 1186 & 524 & 2.669 & 1.545 & 24.577 \\
\hline Шаранский & 138.42 & 95.75 & 33.780 & 24 & 431 & 50 & 0.423 & 0.403 & 7.548 \\
\hline
\end{tabular}

Таблица 2

Показатели заготовки побочной продукции леса по районам на Бугульминско-Белебеевской возвышенности

\begin{tabular}{|c|c|c|c|c|c|c|c|c|}
\hline Район & $\begin{array}{c}\text { Площадь } \\
\text { лесного } \\
\text { фонда } \\
S_{\text {ЛФ }} \text {, тыс. } \\
\text { га }\end{array}$ & $\begin{array}{c}\text { Площадь } \\
\text { липня- } \\
\text { ков } \\
S_{Л}, \text { тыс. га }\end{array}$ & $\begin{array}{c}\text { Объем рубок } \\
\text { ухода } \\
Q_{P y}, \text { тыс. }{ }^{3}\end{array}$ & $\begin{array}{c}\text { Объем } \\
\text { заготовки } \\
\text { плодов } \\
\text { и ягод } \\
Q_{\text {Пя }}, \text { ц }\end{array}$ & $\begin{array}{c}\text { Объем } \\
\text { заготовки } \\
\text { лекарств. } \\
\text { сырья } \\
Q_{\text {ЛС }}, \text { ц }\end{array}$ & $\begin{array}{c}\text { Валовой } \\
\text { выход } \\
\text { сена } \\
Q_{C}, \text { т }\end{array}$ & $\begin{array}{l}\text { Объем } \\
\text { медо- } \\
\text { сбора } \\
Q_{M}, \text { т }\end{array}$ & $\begin{array}{c}\text { Кол-во } \\
\text { пчело } \\
\text { семей } \\
N_{\text {ПС }}, \\
\text { шт. }\end{array}$ \\
\hline Бакалинский & 63.894 & 19.120 & 29.9104 & 78.03 & 6.65 & 465.444 & 71.898 & 3121 \\
\hline Белебеевский & 68.816 & 11.859 & 15.3548 & 50.99 & 6.18 & 243.150 & 48.493 & 1901 \\
\hline Бижбулякский & 34.499 & 0.568 & 9.1416 & 21.50 & 4.61 & 138.300 & 30.379 & 1218 \\
\hline Ермекеевский & 21.738 & 13.072 & 6.7686 & 10.74 & 3.43 & 802.200 & 59.563 & 2006 \\
\hline Миякинский & 39.909 & 8.550 & 10.9030 & 20.50 & 3.76 & 265.311 & 43.479 & 1519 \\
\hline Туймазинский & 74.431 & 25.012 & 18.3007 & 66.40 & 10.50 & 325.767 & 46.477 & 2143 \\
\hline Шаранский & 35.118 & 8.440 & 10.9427 & 12.48 & 2.47 & 150.800 & 32.696 & 1378 \\
\hline
\end{tabular}

Корреляционная матрица. Она показана в таблице 3.

В ней удалены диагональные клетки по ранговым распределениям.

Таблица 3

Корреляционная матрица бинарных отношений факторов

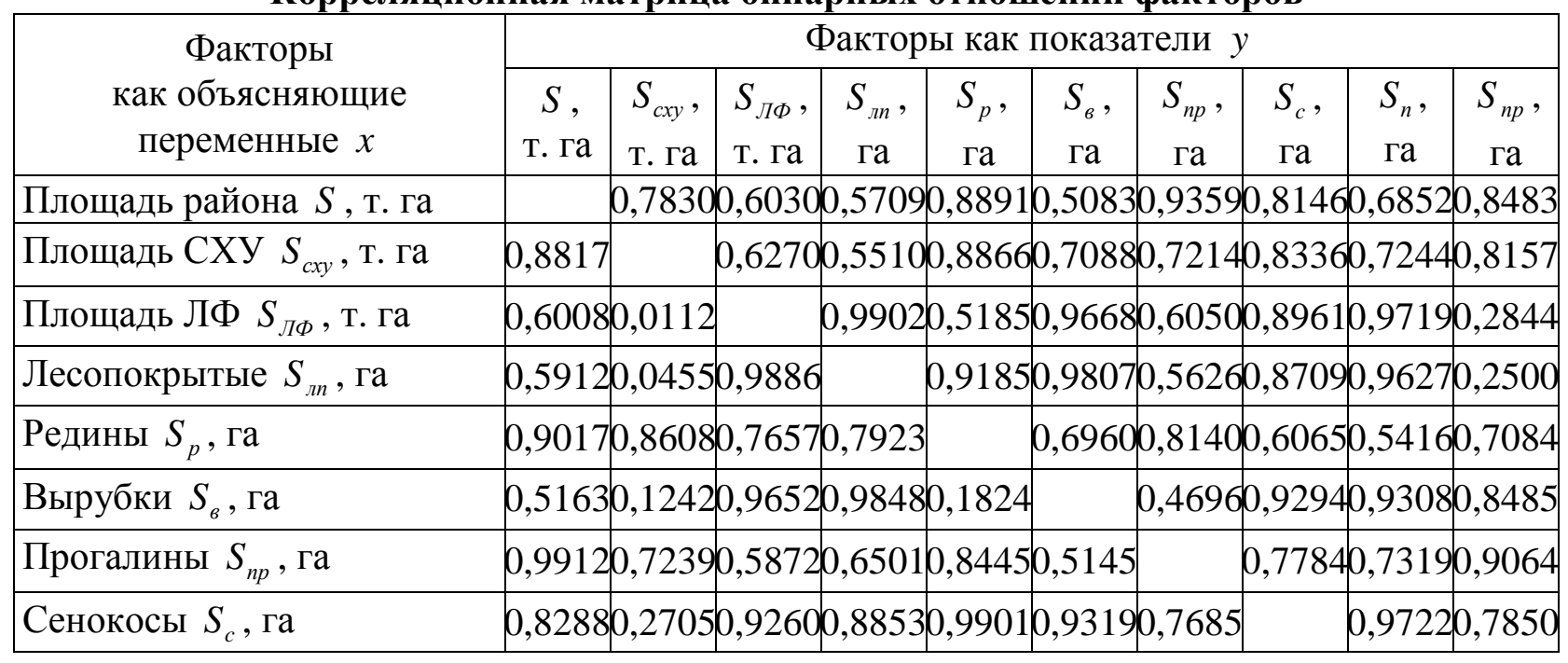




\begin{tabular}{|c|c|c|c|c|c|c|c|c|c|c|}
\hline \multirow{2}{*}{$\begin{array}{c}\text { Факторы } \\
\text { как объясняющие } \\
\text { переменные } x\end{array}$} & \multicolumn{10}{|c|}{ Факторы как показатели $y$} \\
\hline & $\begin{array}{c}S, \\
\text { т. га }\end{array}$ & $\begin{array}{c}S_{c x y}, \\
\text { т. га }\end{array}$ & \begin{tabular}{|l|}
$S_{\text {ЛФ }}$ \\
т. га \\
\end{tabular} & $\begin{array}{c}S_{л n}, \\
\text { га }\end{array}$ & $\begin{array}{c}S_{p}, \\
\text { га }\end{array}$ & $\begin{array}{l}S_{B}, \\
\text { га }\end{array}$ & $\begin{array}{c}S_{n p}, \\
\text { га }\end{array}$ & $\begin{array}{c}S_{c}, \\
\text { га }\end{array}$ & $\begin{array}{c}S_{n}, \\
\text { га }\end{array}$ & $\begin{array}{c}S_{n p}, \\
\text { га }\end{array}$ \\
\hline Пастбища $S_{n}$, га & 0,8479 & 0,227 & 0,9566 & 0,92 & 70 & S & 102 & 9663 & & 0,7965 \\
\hline Прочие земли $S_{n p}$, га & 0,81 & 0,88 & 6255 & 0,62 &, 713 & 67 & 88 & 70 & 7987 & \\
\hline Площадь липняков $S_{J}$, т. га & 0,7750 & $0,7+i$ & $0,70+1$ & 0,01 & & . & 01 & S & 0,0000 & 0,9220 \\
\hline Объем руб. ухода $Q_{P y}$, т. м & 0,5562 & 0,14 & 0,984 & (2) & 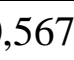 & ור, & 0,56 & טע, & 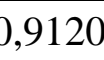 & 0,2091 \\
\hline Объем плодов и ягод $Q_{\text {Пя }}$, ц & 0,82 & , & U & 0,9 & 02 & 9. & 10 &, 04 & $\sigma, 9000$ &, 3655 \\
\hline Объем медосбора $Q_{\mu}$, т & 0,1636 & 0,29 & 0,397 & 72 & 607 & 73 & 37 & 47 & 0,53 & 0,2960 \\
\hline Объем лекар. сырья $Q_{Л С}$, ц & 0,87 & 0,8259 & 0,900 & 0,87 & , 44 & 915 & 809 & 5 & 0,976 & 0,7041 \\
\hline Объем заготовки сена $Q_{C}, \mathrm{~T}$ & 0,66 & $\ln 30$ & 085 & 980 & 720 & 8 & 4 & 8 & 0,812 & 0,2326 \\
\hline К-во пчелосемей $N_{\text {ПС }}$, шт. & 0,127 & 0,258 & 0,548 & 0,52 & 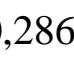 & 0,6 & 15 & 17 & 56 & 50,083 \\
\hline
\end{tabular}

Корреляционная матрица бинарных отношений факторов

Продолжение табл. 3

Последовательным удалением клеток матрицы с меньшими значениями адекватности получают наборы усиливающихся по тесноте факторной связи биотехнических закономерностей.

Известно, что бинарные отношения при коэффициенте корреляции менее 0,3 считаются отсутствующими по закономерностям (табл. 4). 
Корреляционная матрица бинарных отношений факторов при $r \geq 0,3$

\begin{tabular}{|c|c|c|c|c|c|c|c|c|c|c|}
\hline \multirow{3}{*}{$\begin{array}{c}\text { Факторы } \\
\text { как объясняющие } \\
\text { переменные } x\end{array}$} & \multicolumn{10}{|c|}{ Факторы как показатели } \\
\hline & $S$ & $S_{c x y}$ & $S_{\text {ЛФ }}$ & $S_{\text {лn }}$ & $S_{p}$ & $S_{B}$, & $S_{n p}$ & $S_{c}$ & $S_{n}$ & $S_{n p}$, \\
\hline & & т. га & т. га & & га & га & га & га & га & га \\
\hline 1010 & \multicolumn{10}{|c|}{$0,78300,60300,57090,88910,50830,93590,81460,68520,8483$} \\
\hline Площадь С & 3817 & & \multicolumn{8}{|c|}{$0,62700,55100,88660,70880,72140,83360,72440,8157$} \\
\hline Ллощадь J & 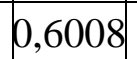 & & \multicolumn{8}{|c|}{$0,99020,51850,96680,60500,89610,9719$} \\
\hline Лесопокрытые $S_{n}$ & 14 & & 0,9886 & \multicolumn{7}{|c|}{$0,91850,98070,56260,87090,9627$} \\
\hline Редины $S_{p}$ & $7 \mathrm{C}$ & & 0,7657 & & & \multicolumn{5}{|c|}{$0,69600,81400,60650,54160,7084$} \\
\hline Вырубки $S_{6}$ & & & 0,9652 & 0 & & \multicolumn{5}{|c|}{$0,46960,92940,93080,8485$} \\
\hline рогалины $S_{n p}$, га & 20 & 0 & 0,5872 & \multicolumn{3}{|c|}{$20,65010,84450,5145$} & \multicolumn{4}{|c|}{$0,77840,73190,9064$} \\
\hline енокосы $S_{c}$, га & 8 & & 0,9260 & \multicolumn{4}{|c|}{$00,88530,99010,93190,7685$} & \multicolumn{3}{|c|}{$0,97220,7850$} \\
\hline Тастбища $S_{n}$, га & 9 & & 0,9566 & \multicolumn{2}{|c|}{$60,92460,7856$} & 0,9500 & 10 & & \multicolumn{2}{|r|}{0,7965} \\
\hline Прочие земли $S_{n p}$, га & 0,8132 & 0 & 0,6255 & \multicolumn{2}{|c|}{$50,62290,713$} & $67 t$ & 8835 & 0 & 7987 & \\
\hline Площадь липняков $S_{J}$ & & & +1 & \multicolumn{2}{|c|}{$10,67960,6649$} & 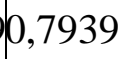 & 51 & 11 & , & 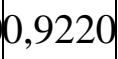 \\
\hline Объем руб. ухода $Q_{P y}$ & 0,5562 & & 0,9849 & \multicolumn{2}{|c|}{$90,98110,5675$} & 0,99 &, 56 & 0,90 &, 9120 & \\
\hline Объем плодов и ягод & $-5 \mathrm{ct}$ & 56 & 4 & \multicolumn{2}{|c|}{$40,95960,8263$} & 0,95 & $70^{\prime}$ & {$\left[, 0^{4}\right.$} & 9000 & 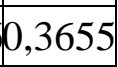 \\
\hline Объем медосбора $Q_{\mu}, \mathrm{T}$ & & & 0,3972 & \multicolumn{2}{|c|}{$20,72820,6074$} & 0,7362 & 20,37 & 0,4 &, 5387 & \\
\hline Объем лекар. сырья $Q_{J C}$, ц & + & U & 9003 & \multicolumn{2}{|c|}{$30,87330,4451$} & 0,91 & 80 & 4 & , & 10 \\
\hline Объем заготовки сена $Q_{C}$, т & & 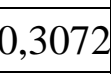 & 0,8560 & \multicolumn{2}{|c|}{$00,80500,720$} & 0,80 & 20,4951 & 0,8807 & 0,8129 & \\
\hline К-во пчелосемей $N_{\Pi C}$, шт. & & & 0,5483 & \multicolumn{2}{|c|}{30,5278} & 0,6465 & & 0,4780 & 0,56 & \\
\hline
\end{tabular}

Продолжение табл. 4 Корреляционная матрица бинарных отношений факторов при $r \geq 0,3$

\begin{tabular}{|c|c|c|c|c|c|c|c|}
\hline \multirow{2}{*}{$\begin{array}{c}\text { Факторы } \\
\text { как объясняющие } \\
\text { переменные } x\end{array}$} & \multicolumn{7}{|c|}{ Факторы как показатели $y$} \\
\hline & $\begin{array}{c}S_{J}, \\
\text { т. га }\end{array}$ & $\begin{array}{l}Q_{P V}, \\
\text { т. }{ }^{3}\end{array}$ & $\begin{array}{c}Q_{\text {Пя }}, \\
\text { ц }\end{array}$ & $Q_{M}$, & $\begin{array}{c}Q_{\text {ЛС }}, \\
\text { ц }\end{array}$ & $\begin{array}{c}Q_{C}, \\
\mathrm{~T}\end{array}$ & $\begin{array}{c}N_{\text {ПС }}, \\
\text { Шт. }\end{array}$ \\
\hline Площадь района $S$, т. га & & 0,3637 & 0,5528 & & 0,7702 & 0,3422 & \\
\hline Площадь СХУ $S_{c x y}$, т. га & 0,9606 & 0,7090 & 0,8371 & 0,9040 & 0,8011 & 0,6797 & 0,9105 \\
\hline Площадь ЛФ $S_{\text {ЛФ }}$, т. га & 0,7655 & 0,7472 & 0,9116 & 0,9601 & 0,8990 & 0,9736 & 0,9012 \\
\hline Лесопокрытые $S_{\text {лл }}$, га & 0,8637 & 0,9037 & 0,9191 & 0,9070 & 0,9200 & 0,9658 & 0,8740 \\
\hline Редины $S_{p}$, га & & 0,7750 & 0,7354 & 0,4288 & 0,5507 & 0,9352 & \\
\hline Вырубки $S_{\theta}$, га & 0,9317 & 0,8334 & 0,9900 & 0,9530 & 0,9006 & & 0,9766 \\
\hline Прогалины $S_{n p}$, га & 0,7669 & & 0,8958 & 0,7607 & 0,8319 & 0,6068 & \\
\hline Сенокосы $S_{c}$, га & 0,9997 & 0,9880 & 0,9753 & 0,7653 & 0,9574 & 0,5898 & 0,9243 \\
\hline Пастбища $S_{n}$, га & 8231 & 0,8080 & 0,9392 & 0,6232 & 0,9750 & & 0,7056 \\
\hline Прочие земли $S_{n p}$, га & 0,7784 & & & 0,8013 & 0,7245 & 0,6603 & 0,6824 \\
\hline Площадь липняков $S_{J}$, т. га & & 0,9440 & 0,8788 & 0,9678 & 0,9230 & 0,9891 & 0,9894 \\
\hline Объем рубок ухода $Q_{P y}$, т. м $^{3}$ & 0,7160 & & 0,9772 & 0,7417 & 0,7996 & 0,9868 & 0,8969 \\
\hline Объем плодов и ягод $Q_{\text {Пя }}$, ц & 0,9558 & 0,9531 & & 0,7786 & 0,8617 & & 0,9404 \\
\hline
\end{tabular}




\begin{tabular}{|c|c|c|c|c|c|c|c|}
\hline \multirow{2}{*}{$\begin{array}{c}\text { Факторы } \\
\text { как объясняющие } \\
\text { переменные } x\end{array}$} & \multicolumn{7}{|c|}{ Факторы как показатели $y$} \\
\hline & $\begin{array}{c}S_{Л}, \\
\text { т. га }\end{array}$ & $\begin{array}{l}Q_{P y}, \\
\text { т. } \mathrm{M}^{3}\end{array}$ & $\begin{array}{c}Q_{\text {ПЯ }}, \\
\text { ц } \\
\end{array}$ & $\begin{array}{c}Q_{M}, \\
\mathrm{~T}\end{array}$ & $\begin{array}{c}Q_{\text {ЛС }}, \\
ц\end{array}$ & $\begin{array}{c}Q_{C}, \\
\mathrm{~T}\end{array}$ & $\begin{array}{c}N_{\text {ПС }}, \\
\text { ШТ. }\end{array}$ \\
\hline Объем медосбора $Q_{M}$, т & 0,6952 & 0,7291 & 0,5760 & & 0,4037 & 0,9746 & 0,9416 \\
\hline Объем лекарств. сырья $Q_{\text {ЛC }}$, ц & 0,7875 & 0,7185 & 0,9913 & 0,4617 & & & 0,9304 \\
\hline Объем заготовки сена $Q_{C}, \mathrm{~T}$ & 0,8385 & 0,7889 & 0,8688 & 0,9246 & 0,7180 & & 0,8668 \\
\hline Кол-во пчелосемей $N_{\text {ПС }}$, шт. & 0,8913 & 0,8773 & 0,7948 & 0,9371 & 0,6107 & 0,6598 & \\
\hline
\end{tabular}

Затем оставим сильные бинарные отношения при $r \geq 0,7$ (табл. 5).

Таблица 5

Корреляционная матрица бинарных отношений факторов при $r \geq 0,7$

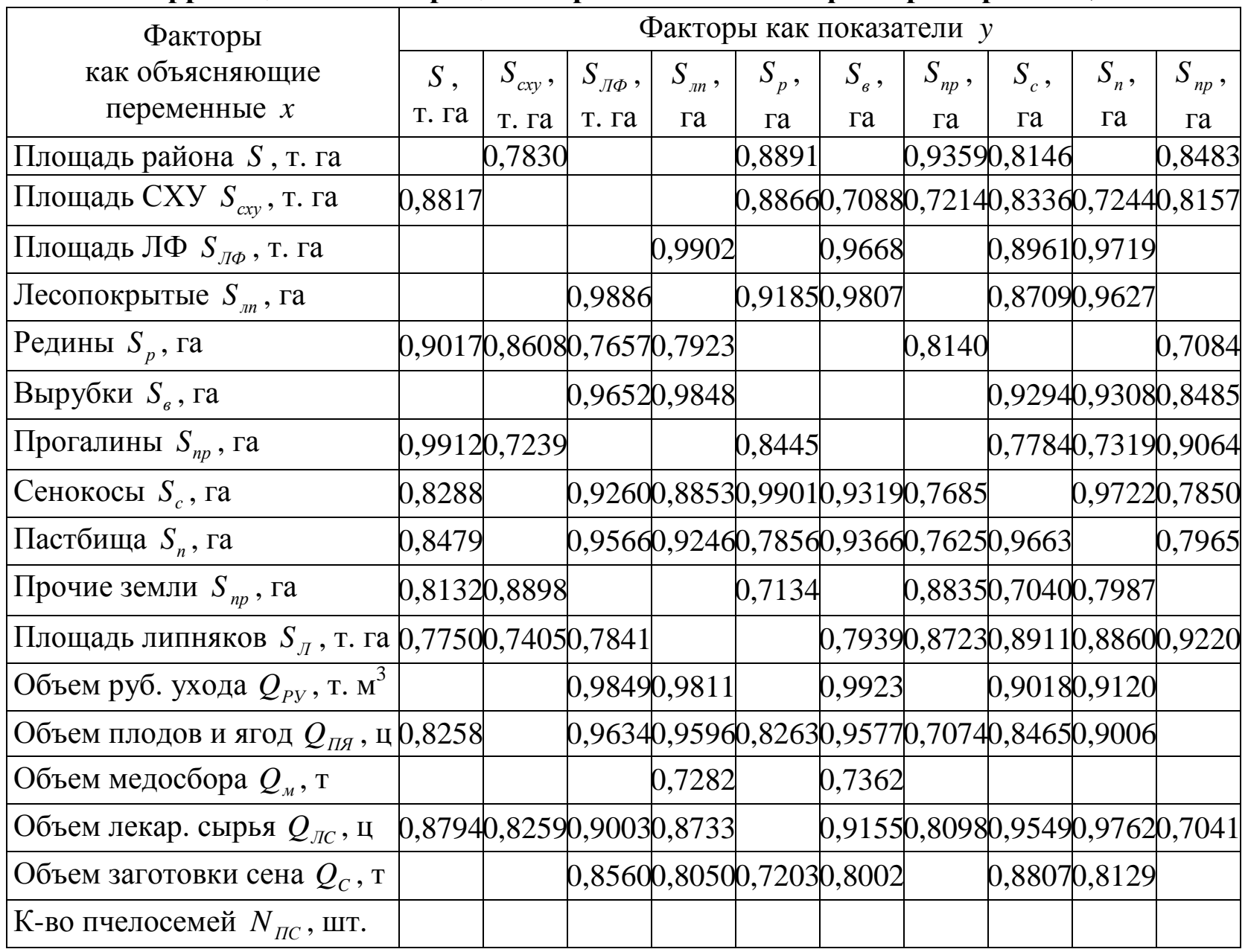

Продолжение табл. 5

Корреляционная матрица бинарных отношений факторов при $r \geq 0,7$

\begin{tabular}{|c|c|c|c|c|c|c|c|}
\hline \multirow{2}{*}{$\begin{array}{c}\text { Факторы } \\
\text { как объясняющие } \\
\text { переменные } x\end{array}$} & \multicolumn{7}{|c|}{ Факторы как показатели $y$} \\
\hline & $\begin{array}{c}S_{\text {Л }}, \\
\text { т. га }\end{array}$ & $\begin{array}{l}Q_{P y}, \\
\text { T. } \mathrm{M}^{3}\end{array}$ & $\begin{array}{c}Q_{\text {ПЯ }}, \\
\text { ц }\end{array}$ & $\begin{array}{c}Q_{\mu}, \\
\mathrm{T}\end{array}$ & $\begin{array}{c}Q_{\text {ЛС }}, \\
ц\end{array}$ & $\begin{array}{c}Q_{C}, \\
\mathrm{~T}\end{array}$ & $\begin{array}{c}N_{\text {ПС }}, \\
\text { ШТ. }\end{array}$ \\
\hline Площадь района $S$, т. га & & & & & 0,7702 & & \\
\hline Площадь СХУ $S_{c x y}$, т. га & 0,9606 & 0,7090 & 0,8371 & 0,9040 & 0,8011 & & 0,9105 \\
\hline Площадь ЛФ $S_{Л \Phi}$, т. га & 0,7655 & 0,7472 & 0,9116 & 0,9601 & 0,8990 & 0,9736 & 0,9012 \\
\hline Лесопокрытые $S_{л n}$, га & 0,8637 & 0,9037 & 0,9191 & 0,9070 & 0,9200 & 0,9658 & 0,8740 \\
\hline
\end{tabular}




\begin{tabular}{|c|c|c|c|c|c|c|c|}
\hline \multirow{2}{*}{$\begin{array}{c}\text { Факторы } \\
\text { как объясняющие } \\
\text { переменные } x \\
\end{array}$} & \multicolumn{7}{|c|}{ Факторы как показатели $y$} \\
\hline & $\begin{array}{c}S_{\text {Л }}, \\
\text { т. га }\end{array}$ & $\begin{array}{l}Q_{P y}, \\
\text { т. }{ }^{3}\end{array}$ & $\begin{array}{c}Q_{\text {Пя }}, \\
\text { Ц } \\
\end{array}$ & $\begin{array}{c}Q_{M}, \\
\mathrm{~T}\end{array}$ & $\begin{array}{c}Q_{Л C}, \\
ц\end{array}$ & $\begin{array}{c}Q_{C}, \\
\mathrm{~T}\end{array}$ & $\begin{array}{c}N_{\Pi C}, \\
\text { ШТ. }\end{array}$ \\
\hline Редины $S_{p}$, га & & 0,7750 & 0,7354 & & & 0,9352 & \\
\hline Вырубки $S_{\theta}$, га & 0,9317 & 0,8334 & 0,9900 & 0,9530 & 0,9006 & & 0,9766 \\
\hline Прогалины $S_{n p}$, га & 0,7669 & & 0,8958 & 0,7607 & 0,8319 & & \\
\hline Сенокосы $S_{c}$, га & 0,9997 & 0,9880 & 0,9753 & 0,7653 & 0,9574 & & 0,9243 \\
\hline Пастбища $S_{n}$, га & 0,8231 & 0,8080 & 0,9392 & & 0,9750 & & 0,7056 \\
\hline Прочие земли $S_{n p}$, га & 0,7784 & & & 0,8013 & 0,7245 & & \\
\hline Площадь липняков $S_{Л}$, т. га & & 0,9440 & 0,8788 & 0,9678 & 0,9230 & 0,9891 & 0,9894 \\
\hline Объем рубок ухода $Q_{P y}$, т. м ${ }^{3}$ & 0,7160 & & 0,9772 & 0,7417 & 0,7996 & 0,9868 & 0,8969 \\
\hline Объем плодов и ягод $Q_{\text {пя }}$, ц & 0,9558 & 0,9531 & & 0,7786 & 0,8617 & & 0,9404 \\
\hline Объем медосбора $Q_{m}$, т & & 0,7291 & & & & 0,9746 & 0,9416 \\
\hline Объем лекарств. сырья $Q_{\text {ЛС }}$, ц & 0,7875 & 0,7185 & 0,9913 & & & & 0,9304 \\
\hline Объем заготовки сена $Q_{C}$, т & 0,8385 & 0,7889 & 0,8688 & 0,9246 & 0,7180 & & 0,8668 \\
\hline Кол-во пчелосемей $N_{\Pi C}$, шт. & 0,8913 & 0,8773 & 0,7948 & 0,9371 & & & \\
\hline
\end{tabular}

Все столбцы и строки корреляционной матрицы сохранились. Оставшиеся в таблице 5 множество из 180 формул можно использовать при построении имитационной модели поведения системы. Далее оставим в матрице только сильнейшие связи при $r \geq 0,6$ (табл. 6) и уберем пустые строки и столбцы.

Таблица 6

Корреляционная матрица бинарных отношений факторов при $r \geq 0,9$

\begin{tabular}{|c|c|c|c|c|c|c|c|c|c|c|c|c|c|c|c|c|}
\hline$x$ & $\begin{array}{c}S, \\
\text { т. га } \\
\end{array}$ & \begin{tabular}{|c|}
$S_{\text {ЛФ }}$ \\
т. га \\
\end{tabular} & $\begin{array}{c}S_{л n} \\
\text { га }\end{array}$ & $\begin{array}{c}S_{p} \\
\text { га }\end{array}$ & $\begin{array}{c}S_{B}, \\
\text { га }\end{array}$ & $\begin{array}{c}S_{n p}, \\
\text { га } \\
\end{array}$ & $\begin{array}{c}S_{c}, \\
\text { га }\end{array}$ & $\begin{array}{c}S_{n}, \\
\text { га }\end{array}$ & $\begin{array}{c}S_{n p}, \\
\text { га } \\
\end{array}$ & $\begin{array}{c}S_{Л}, \\
\text { т. га } \\
\end{array}$ & $\begin{array}{l}Q_{P Y} \\
\text { T. }{ }^{3}\end{array}$ & $\begin{array}{c}Q_{\text {Пя }}, \\
\text { ц }\end{array}$ & $\begin{array}{c}Q_{u}, \\
\mathrm{~T}\end{array}$ & $\begin{array}{c}Q_{\text {ЛС }}, \\
\text { ц }\end{array}$ & $\begin{array}{c}Q_{C} \\
\mathrm{~T}\end{array}$ & $\begin{array}{c}N_{\Pi C} \\
\text { шт. }\end{array}$ \\
\hline$S$ & & & & 0,8891 & & 0,9359 & & & & & & & & & & \\
\hline$S_{c x y}$ & & & & & & & & & & 0,9606 & & & 0,9040 & & & 0,9105 \\
\hline$S_{Л \Phi}$ & & & 0,9902 & & 0,9668 & & & 0,9719 & & & & 0,91160 & 0,9601 & & 0,97360 & 60,9012 \\
\hline$S_{\text {лn }}$ & & 0,9886 & & 0,9185 & 50,9807 & & & 0,9627 & & & 0,9037 & 0,91910 & 0,9070 & 0,9200 & 0,9658 & \\
\hline$S_{p}$ & 0,9017 & & & & & & & & & & & & & & 0,9352 & \\
\hline$S_{\text {s }}$ & & 0,9652 & 20,9848 & & & & 0,9294 & 40,9308 & & 0,9317 & & 0,99000 & 0,9530 & 0,9006 & & 0,9766 \\
\hline$S_{n p}$ & 0,9912 & & & & & & & & 0,9064 & & & & & & & \\
\hline$S_{c}$ & & 0,9260 & & 0,9901 & 10,9319 & & & 0,9722 & & 0,9997 & 0,9880 & 0,9753 & & 0,9574 & & 0,9243 \\
\hline$S_{n}$ & & 0,9566 & 0,9246 & & 0,9366 & & 0,9663 & & & & & 0,9392 & & 0,9750 & & \\
\hline$S_{\text {Л }}$ & & & & & & & & & 0,9220 & & 0,9440 & & 0,9678 & 80,9230 & 0,9891 & 0,9894 \\
\hline$Q_{P Y}$ & & 0,9849 & 0,9811 & & 0,9923 & & 0,9018 & 80,9120 & & & & 0,9772 & & & 0,9868 & \\
\hline$Q_{\text {ПЯ }}$ & & 0,9634 & 0,9596 & & 0,9577 & & & 0,9006 & & 0,9558 & 30,9531 & & & & & 0,9404 \\
\hline$Q_{\mu}$ & & & & & & & & & & & & & & & 0,9746 & 0,9416 \\
\hline$Q_{\text {ЛC }}$ & & 0,9003 & & & 0,9155 & & 0,9549 & 90,9762 & & & & 0,9913 & & & & 0,9304 \\
\hline$Q_{C}$ & & & & & & & & & & & & & 0,9246 & & & \\
\hline$N_{\Pi C}$ & & & & & & & & & & & & & 0,9371 & & & \\
\hline
\end{tabular}


Остались 79 формул, удалились одна строка и один столбец. Поэтому ужесточим допустимый уровень коэффициента корреляции до 0,95 (табл. 7).

Таблица 7

Корреляционная матрица бинарных отношений факторов при $r \geq 0,95$

\begin{tabular}{|c|c|c|c|c|c|c|c|c|c|c|c|c|c|c|}
\hline $\begin{array}{c}\text { Пере- } \\
\text { менные } \\
x\end{array}$ & \begin{tabular}{c|}
$S$, \\
т. га
\end{tabular} & $\begin{array}{l}S_{\text {ЛФ }}, \\
\text { т. га }\end{array}$ & $\begin{array}{c}S_{\text {лл }}, \\
\text { га }\end{array}$ & $\begin{array}{l}S_{p}, \\
\text { га }\end{array}$ & $\begin{array}{l}S_{\beta}, \\
\text { га }\end{array}$ & $\begin{array}{l}S_{c}, \\
\text { га }\end{array}$ & $\begin{array}{l}S_{n}, \\
\text { га }\end{array}$ & $\begin{array}{l}S_{Л}, \\
\text { т. га }\end{array}$ & $\begin{array}{l}Q_{P y}, \\
\text { т. } \mathrm{M}^{3}\end{array}$ & $\begin{array}{c}Q_{\text {ПЯ }}, \\
\text { ц }\end{array}$ & $\begin{array}{c}Q_{M}, \\
\mathrm{~T}\end{array}$ & $\begin{array}{c}Q_{\text {ЛС }}, \\
ц\end{array}$ & $\begin{array}{c}Q_{C}, \\
\mathrm{~T}\end{array}$ & $\begin{array}{c}N_{\Pi C}, \\
\text { шт. }\end{array}$ \\
\hline$S_{c x y}$, т. га & & & & & & & & 0,9606 & & & & & & \\
\hline$S_{\text {ЛФ }}$, т. га & & & 0,9902 & & 0,9668 & & 0,9719 & & & & 0,9601 & & 0,9736 & \\
\hline$S_{\text {лл }}$, га & & 0,9886 & & & 0,9807 & & 0,9627 & & & & & & 0,9658 & \\
\hline$S_{в}$, га & & 0,9652 & 0,9848 & & & & & & & 0,9900 & 0,9530 & & & 0,9766 \\
\hline$S_{n p}$, га & 0,9912 & & & & & & & & & & & & & \\
\hline$S_{c}$, га & & & & 0,9901 & & & 0,9722 & 0,9997 & 0,9880 & 0,9753 & & 0,9574 & & \\
\hline$S_{n}$, га & & 0,9566 & & & & 0,9663 & & & & & & 0,9750 & & \\
\hline$S_{Л}$, т. га & & & & & & & & & & & 0,9678 & & 0,9891 & 0,9894 \\
\hline$Q_{P Y}$, т. м $^{3}$ & & 0,9849 & 0,9811 & & 0,9923 & & & & & 0,9772 & & & 0,9868 & \\
\hline$Q_{\text {Пя }}$, ц & & 0,9634 & 0,9596 & & 0,9577 & & & 0,95580 & 0,9531 & & & & & \\
\hline$Q_{\mu}, \mathrm{T}$ & & & & & & & & & & & & & 0,9746 & \\
\hline$Q_{Л C}$, ц & & & & & & 0,95490 & 0,9762 & & & 0,9913 & & & & \\
\hline
\end{tabular}

Осталось множеств из 42 формул. Однако для демонстрации метода факторного анализа в статье этого количества также много. Поэтому, наконец, дадим самый высокий уровень требований к допустимому значению коэффициента корреляции 0,99 (табл. 8)

Таблица 8

Корреляционная матрица бинарных отношений факторов при $r \geq 0,99$

\begin{tabular}{|c|c|c|c|c|c|c|}
\hline \multirow{2}{*}{$\begin{array}{c}\text { Факторы } \\
\text { как объясняющие } \\
\text { переменные } x\end{array}$} & \multicolumn{6}{|c|}{ Факторы как показатели $y$} \\
\hline & $\begin{array}{c}S, \\
\text { т. га }\end{array}$ & $\begin{array}{c}S_{л n}, \\
\text { га }\end{array}$ & $\begin{array}{l}S_{p}, \\
\text { га }\end{array}$ & $\begin{array}{l}S_{B}, \\
\text { га }\end{array}$ & $\begin{array}{c}S_{\text {Л }}, \\
\text { т. га }\end{array}$ & $\begin{array}{c}Q_{\text {Пя }}, \\
\text { ц }\end{array}$ \\
\hline Площадь ЛФ $S_{\text {ЛФ }}$, т. га & & 0,9902 & & & & \\
\hline Вырубки $S_{\theta}$, га & & & & & & 0,9900 \\
\hline Прогалины $S_{n p}$, га & 0,9912 & & & & & \\
\hline Сенокосы $S_{c}$, га & & & 0,9901 & & 0,9997 & \\
\hline Объем рубок ухода $Q_{P y}$, т. м ${ }^{3}$ & & & & 0,9923 & & \\
\hline Объем лекарств. сырья $Q_{\text {ЛС }}$, ц & & & & & & 0,9913 \\
\hline
\end{tabular}

Наиболее высокий коэффициент корреляции 0,9997 получила закономерность изменения площади липняков в зависимости от площади сенокосов (рис. 2). Ранжируем выявленные закономерности и значения параметров модели (1) поместим по убыванию тесноты связи в таблице 9.

Статистическое моделирование позволяет выявить высокоадекватные тренды взаимной зависимости площади компонент сельхозугодий по общей формуле (1). При большем количестве районов, по-видимому, появятся и до- 
полнительные к тренду волновые закономерности. Для этого нужно будет собрать данные по 17 показателям по всем районам Республики Башкортостан.

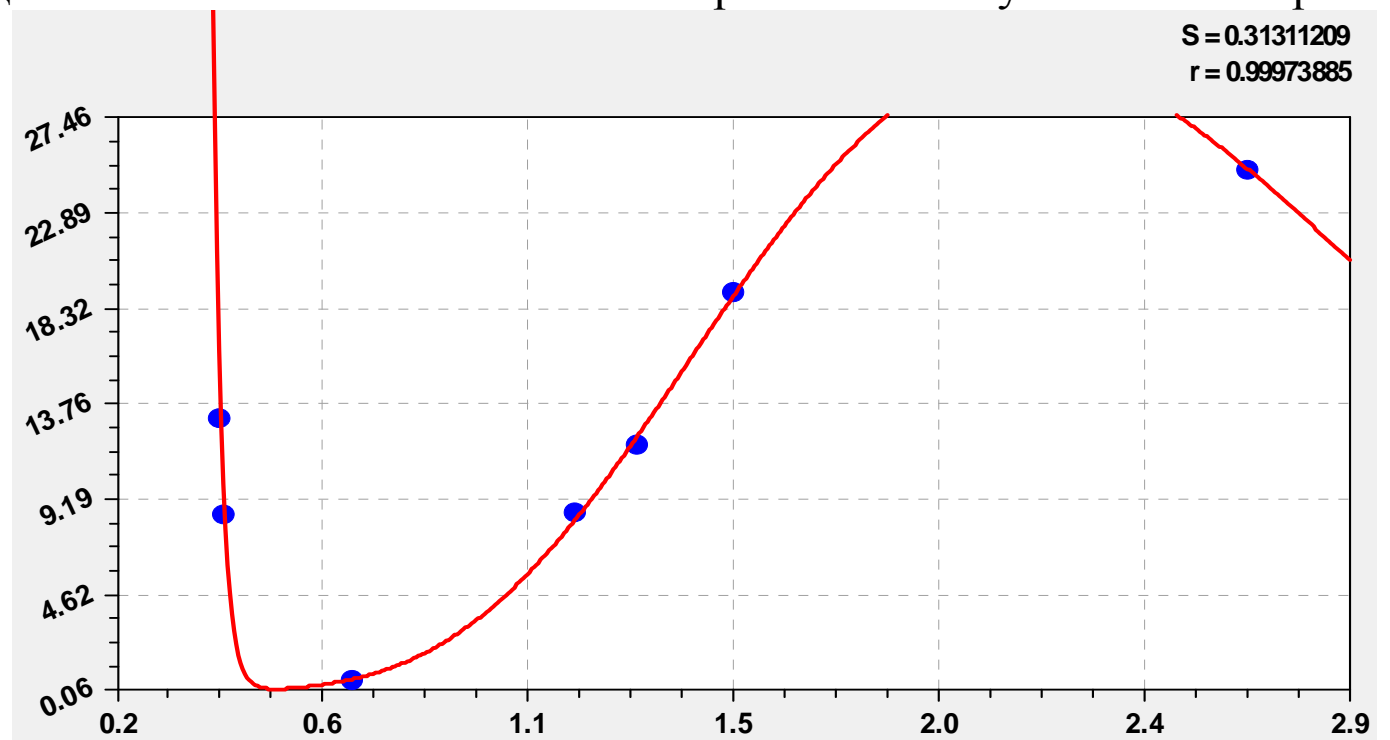

Рисунок 2. Изменение площади липняков в зависимости от площади сенокосов
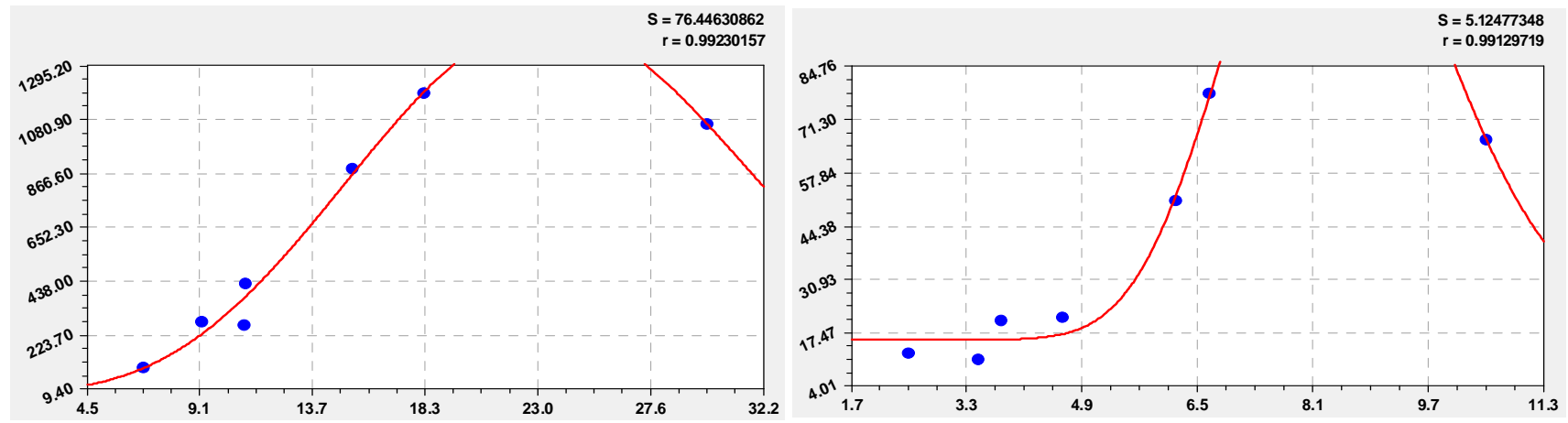

объем рубок ухода на площадь вырубок
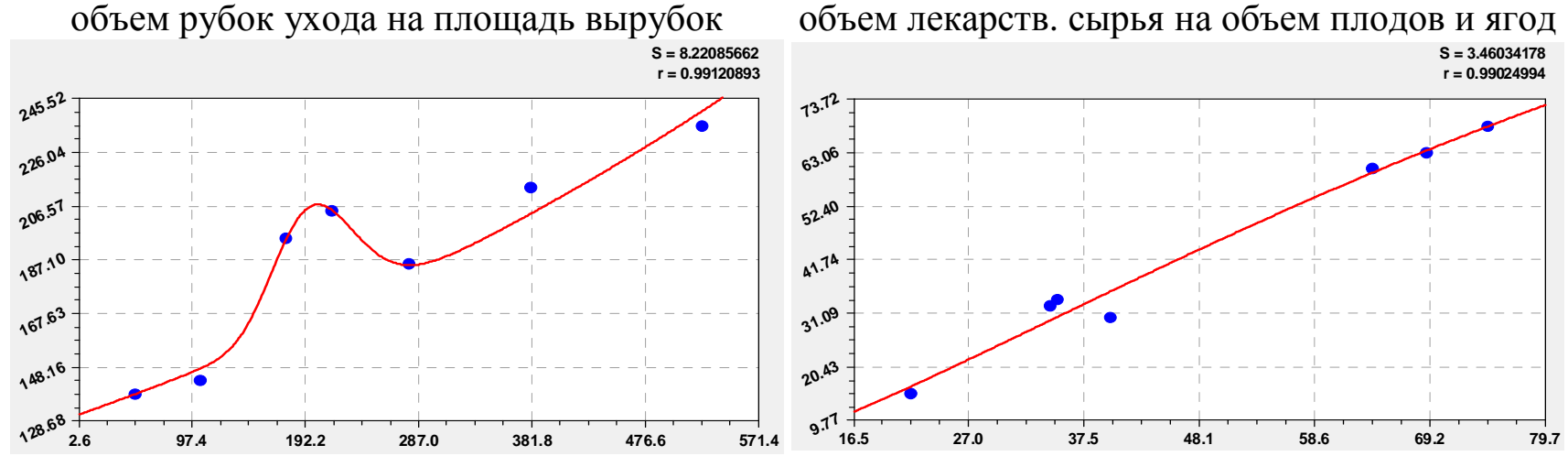

площадь прогалин на общую площадь района

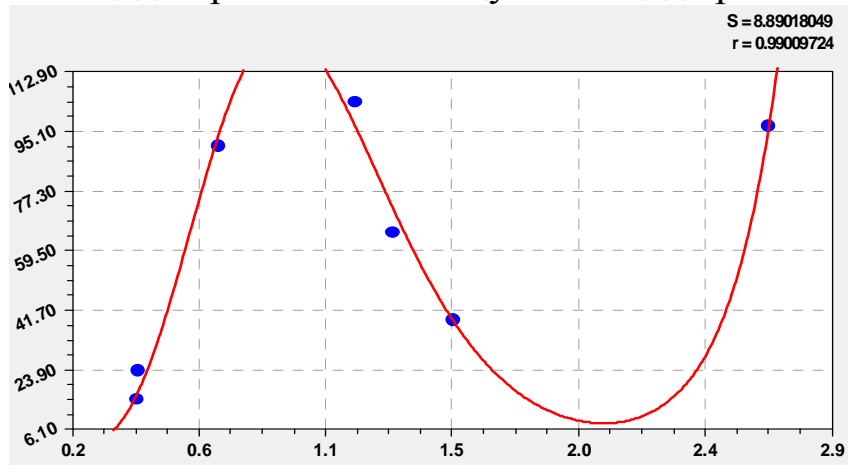

площадь ЛФ на лесопокрытые площади

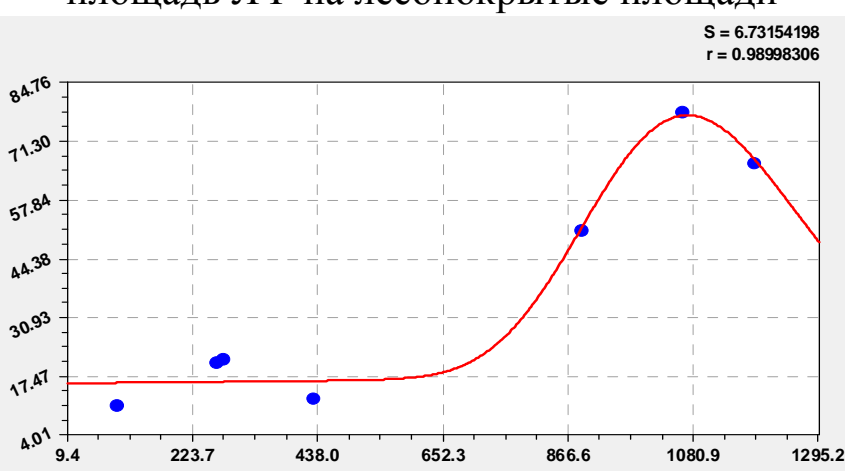

площадь сенокосов на площадь редин

площадь вырубок на объем плодов и ягод

Рис. 3. Графики сверхсильных факторных связей по таблице 9 
В дальнейших исследованиях, например, нужно разделить данные по отдельным годам, чтобы получить динамику значений показателей с 2006 года.

Рейтинг бинарных отношений при коэффициенте корреляции $r \geq 0,99$

\begin{tabular}{|c|c|c|c|c|c|c|c|c|c|c|}
\hline \multirow{3}{*}{$\begin{array}{l}\text { № } \\
\text { П/П }\end{array}$} & \multirow{3}{*}{$\begin{array}{l}\text { Форма } \\
x \rightarrow y\end{array}$} & \multicolumn{8}{|c|}{$y=a_{1} x^{a_{2}} \exp \left(-a_{3} x^{a_{4}}\right)+a_{5} x^{a_{6}} \exp \left(-a_{7} x^{a_{8}}\right)$} & \multirow{3}{*}{\begin{tabular}{|c} 
Коэф. \\
корр. \\
$r$ \\
\end{tabular}} \\
\hline & & \multicolumn{4}{|c|}{ Первая составляющая } & \multicolumn{4}{|c|}{ Вторая составляющая } & \\
\hline & & $a_{1}$ & $a_{2}$ & $a_{3}$ & $a_{4}$ & $a_{5}$ & $a_{6}$ & $a_{7}$ & $a_{8}$ & \\
\hline 1 & $S_{c}-S_{J}$ & $4,88289 \mathrm{e} 10$ & 0 & 53,12461 & 1 & 203,65909 & 8,65810 & 3,97026 & & 0,9997 \\
\hline 2 & $Q_{P V}-S_{\theta}$ & 0,25968 & 3,10511 & 0,00022949 & 2,70260 & 0 & 0 & 0 & 0 & 0,9923 \\
\hline 3 & $Q_{\text {ЛС }}-Q_{\text {ПЯ }}$ & $8,57279 \mathrm{e}-14$ & 31,24333 & 3,75734 & 1 & 15,78225 & 0 & 0 & 0 & 9913 \\
\hline 4 & $S_{n p}-S$ & 130,07761 & 0 & $-0,0011674$ & 1 & $6,41854 \mathrm{e}-6$ & 33,77430 & 0,17154 & 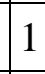 & 0,9912 \\
\hline 5 & $S_{Л \Phi}-S_{л n}$ & 0,20618 & 1,47960 & 0,0077056 & 1 & 0 & 0 & 0 & U & 0,9902 \\
\hline 6 & $S_{c}-S_{p}$ & $3,35628 \mathrm{e}-5$ & 0 & $-5,57309$ & 1 & 585640,07 & 7,92904 & 8,47027 & & 0,9901 \\
\hline 7 & $S_{в}-Q_{\text {ПЯ }}$ & 15,83210 & 0 & $-9,00623 e-5$ & 1 & $1,73447 \mathrm{e}-88$ & 34,50761 & 0,032277 & & 0,9900 \\
\hline
\end{tabular}

Графики показывают, что между факторами существует сложная взаимная связь. При этом на каждом графике заметны минимум и максимум. Этот факт означает, что вполне можно создать имитационную модель из формул таблицы 7, позволяющих провести оптимизацию с целью повышения выхода недревесной продукции.

Заключение. Факторный анализ, по сравнению с существующими методами линейного моделирования, позволяет выявить по общей модели (1) тренды высокой адекватности. При этом всегда получаются только нелинейные модели. В дальнейшем можно дополнительно к трендам получать и волновые составляющие, но для этого нужно подготовить табличные данные по всем районам Республики Башкортостан, включая города и крупные населенные пункты. Это позволит получить объективную картину распределения земельного кадастра и показателей недревесной продукции леса.

\section{Список литературы:}

1. Мазуркин П.М. Биокаркас территории: учеб. пос. с грифом УМО РАЕ. Йошкар-Ола: Поволжский ГТУ, 2013. 156 с.

2. . Мазуркин П.М., Евдокимова А.Ю. Факторный анализ и динамика загрязнения речной воды. Йошкар-Ола: ПГТУ, 2012. 42 с.

3. Мазуркин П. М., Михайлова С.И. Территориальное экологическое равновесие $=$ Territprial ecological balance: аналит. обзор; Учреждение Рос. акад. наук Гос. публич. науч.-техн. б-ка Сиб. отд-ния РАН. Новосибирск: ГПНТБ СО РАН, 2010. 430 с. (Сер. Экология. Вып. 94).

4. Мазуркин П.М., Тарасова Е.Н. Закономерности показателей качества воды родников. Йошкар-Ола: ПГТУ, 2012. 131 с.

5. Мазуркин П.М., Филонов А.С. Математическое моделирование. Идентификация однофакторных статистических закономерностей: учеб. пос. Йошкар-Ола: МарГТУ, 2006. 292 с. 
6. Хисамов Р.Р. Хозяйственно-ценный фитоценоз в защитных лесных насаждениях на агроландшафтах Белебеевской возвышенности Республики Башкортостан / Хисамов Р.Р., Рахматуллина И.Р., Рахматуллин 3.З., Хасанов Ф.Ф. // Материалы международной научно-практической конференции «Сберегающие (биологическое) земледелие в современном сельском хозяйстве». Уфа: Гилем, Башк.энцикл., 2014. 244 с.

7. Хисамов Р.Р., Кулагин А.А. Биологические ресурсы Республики Башкортостан: недревесные ресурсы леса. Уфа: Изд-во БГПУ, 2014. 292 с. 